\title{
CONCENTRATION OF PHOTOSYNTHETIC PIGMENTS AND CHLOROPHYLL FLUORESCENCE OF MAHOGANY AND TONKA BEAN UNDER TWO LIGHT ENVIRONMENTS
}

\author{
JOSÉ FRANCISCO DE CARVALHO GONÇALVES ${ }^{1}$, RICARDO ANTONIO \\ MARENCO $^{1}$ AND GIL VIEIRA ${ }^{1}$
}

\author{
Coordenação de Pesquisas em Silvicultura Tropical, Instituto Nacional de Pesquisas da Amazônia \\ (INPA), C.P. 478, 69011-970, Manaus, AM, Brasil.
}

\begin{abstract}
This study was carried out in a plantation of a degraded area in Central Amazon, Brazil, in order to assess environmental light effects on leaf pigment concentrations and chlorophyll $a$ fluorescence in mahogany (Swietenia macrophylla King) and tonka bean (Dipteryx odorata Aubl. Willd). Three-year old saplings were grown in an open site (sun) with maximum radiation of approximately 2000 $\mu \mathrm{mol} \mathrm{m} \mathrm{m}^{-1}$ and under the shade of a Ochroma pyramidale (Cav. ex Lam. Urb) canopy. A leaf area index of 2.46 was optically determined for the Ochroma foliage with $13 \%$ of full sunlight (maximum radiation about $260 \mu \mathrm{mol} \mathrm{m} \mathrm{m}^{-2} \mathrm{~s}^{-1}$ ). Carotenoid and chlorophyll concentrations were spectrophotometrically determined. Initial $\left(\mathrm{F}_{\mathrm{o}}\right)$, maximum $\left(\mathrm{F}_{\mathrm{m}}\right)$ and variable fluorescence $(\mathrm{Fv})$ were determined with a portable fluorometer. Chlorophyll concentrations ( $\mathrm{Chl} a, \mathrm{Chl} b$ and $\mathrm{Chl} t o t)$ on a fresh mass basis were greater in shade leaves than in sun acclimated leaves in both species. On the other hand, when comparisons were made on a per area basis, Chl $a$ concentrations were greater in the sun than in shade leaves of tonka bean. In contrast, $\mathrm{Chl} b$ concentrations were higher in the shade environment for this species. No differences were observed in $\mathrm{Chl}$ concentrations per unit area in mahogany leaves. Carotenoid concentrations were higher for sun-acclimated leaves of mahogany, both on a per unit area and on a fresh mass basis. In tonka bean, higher carotenoid concentrations in shade leaves were only observed on a fresh weight basis. No differences were found between environments when carotenoid concentrations were expressed as a function of leaf area. Fluorescence variables $\left(F_{o}, F_{m}\right.$, and $\left.F_{v}\right)$ were greater in sun leaves than in shade leaves of mahogany. In contrast, $F_{v}$ and $F_{m}$, but not $F_{o}$, values were higher in shade acclimated leaves than in full sunlight-adapted leaves of tonka bean. However, there was a higher $F_{v} / F_{m}$ ratio value for tonka bean in sunlight environments. We conclude that these species, classified as mid and late successional species, differ markedly regarding the utilization of photosynthetic pigments, increasing either light harvesting efficiency at low irradiance or protection against photosynthetic machinery damage in higher solar radiation environments.
\end{abstract}

ADDITIONAL INDEX TERMS: Carotenoid, Dipteryx odorata, Swietenia macrophylla, tropical species.

Received: 23.03.2001 - Accepted: 26.06.2001

1 Coordenação de Pesquisas em Silvicultura Tropical, INPA / MCT, 69011.970, Manaus, AM, Brasil

* Author to whom correspondence should be addressed (email: jfc@inpa.gov.br) 


\section{CONCENTRAÇÃO DE PIGMENTOS FOTOSSINTÉTICOS E FLUORESCÊNCIA DA CLOROFILA EM MOGNO E CUMARU SOB DOIS AMBIENTES DE LUZ}

RESUMO - Estudou-se o efeito do ambiente de luz sobre as concentrações dos pigmentos fotossintéticos e a fluorescência da clorofila $a$ em plantas de mogno (Swietenia macrophylla King) e de cumaru (Dipteryx odorata Aubl. Willd), com o objetivo de analisar a eficiência fotossintética dessas espécies sob dois ambientes de luz em plantio sob área degradada, na Amazônia Central, Brasil. Utilizaram-se plantas jovens, com 3 anos de idade, em plantio a céu aberto (sol) com cerca de $2000 \mu \mathrm{mol} \mathrm{m}^{-2} \mathrm{~s}^{-1}$ e sob cobertura natural do dossel de plantas (sombra) de pau-de-balsa (Ochroma pyramidale Cav. Ex Lam. Urb) com índice de área foliar de 2,46 e sombreamento de $13 \%$ da luz no ambiente aberto com cerca de $260 \mu \mathrm{mol}$ $\mathrm{m}^{-2} \mathrm{~s}^{-1}$. As concentrações dos carotenóides e das clorofilas foram determinadAs por espectrofotometria, e a fluorescência, utilizando-se um fluorômetro portátil. Analisando-se as variáveis: fluorescência inicial $\left(F_{o}\right)$, fluorescência máxima $\left(F_{m}\right)$, fluorescência variável $\left(F_{v}\right)$ e a razão $F_{v} / F_{m}$, constatou-se que as concentrações de clorofila (Chl) $a, b$ e total em $\mu$ mol. $\mathrm{g}^{-1} \mathrm{MF}$, nas duas espécies, foram maiores no ambiente de sombra quando comparadAs com o ambiente de sol. Por outro lado, no mogno, essas mesmas concentrações, por unidade de área, não foram diferentes para os ambientes sol ou sombra. Porém, no caso do cumaru, as Chl $a$ e total foram maiores no ambiente de sol, enquanto a Chl $b$ continuou maior no ambiente de sombra. Para os carotenóides, tanto por unidade de massa quanto de área, verificaram-se diferenças para o mogno, ou seja, as concentrações de carotenóides foram sempre maiores no ambiente de sol. Por outro lado, no cumaru, por unidade de massa, as concentrações desses pigmentos foram maiores na sombra e por unidade de área não se observaram diferenças entre os ambientes. Quanto à fluorescência, verificou-se que, no mogno, os valores de $F_{o}, F_{m}$ e $F_{v}$ foram sempre maiores no ambiente de sol. Já no cumaru, não verificou-se diferença para $F_{o}$, entre os ambientes. Os valores de $F_{m}$ e $F_{v}$ foram maiores no ambiente de sombra. No ambiente de sol, a razão $\mathrm{F}_{\mathrm{v}} / \mathrm{F}_{\mathrm{m}}$ foi maior nas folhas de cumaru, quando comparada com o mogno. Concluiu-se que essas espécies, classificadas como espécies intermediárias e sucessional tardia, usam estratégias diferentes quanto ao acúmulo e ao uso dos pigmentos fotossintéticos no que se refere à captação de luz em ambientes de menor luminosidade e à proteção contra a fotodestruição em ambientes de maior luminosidade.

TERMOS ADICIONAIS PARA INDEXAÇÃO: Carotenóides, Dipteryx odorata, espécies tropicais Swietenia macrophylla.

\section{INTRODUCTION}

Agricultural projects, selective logging and other human activities have increased considerably over the last decades, causing negative impacts on Amazonian ecosystems and resulting in destroyed and burned vegetation in several parts of the Amazon. Between 1993 and 1997 the logged area was around $38,000 \mathrm{~km}^{2}$, resulting in impoverished, disturbed, abandoned, and degraded areas (Nepstad et al., 1999). Consequently, growth factors such as light, nutrients, and water availability in the soil have changed so drastically that growth and establishment of plants have been severely affected in such areas. In deforested areas in the Amazonian region, early successional (pioneer) species show greater tolerance to new environmental conditions due to a high degree of rusticity and physiological plasticity. On the other hand, in late successional (climax) species, mortality rates are higher and growth is reduced, and reforestation of degraded areas with these species usually does not succeed. Kageyama (1990), suggested that this failure occurs because foresters do not consider the differences in physiological traits and successional stage of native species. Environmental stress during early growth stages in climax species is the 
main cause of this failure. Plants will experience photoinhibition, nutrient deficiencies and water stress during the annual dry season. Light stress is frequent under tropical conditions, and chlorophyll and carotenoid concentrations are indicators of plant responsiveness to light intensity (StraussDebenedetti and Bazzaz, 1991; Vieira, 1996). Chlorophyll tends to be photooxidized at high irradiance and, because carotenoids can prevent chlorophyll photooxidation, the relationship between chlorophyll and carotenoids may be used as a potential indicator of photooxidative damages caused by strong irradiation (Hendry and Price, 1993).

Damage caused by photoinhibition may be assessed by determining fluorescence and emission through chlorophyll $a$ in plants treated with strong irradiation pulses. By measuring the emission of fluorescence, it has been found that photoinhibition is mainly observed in photosystem II, PS II (Krause and Weis, 1991; Shole and Horton, 1993). This non-destructive technique has been a common approach for estimating PS II efficiency and recently further attention has been focused on plants subjected to low temperature and high irradiance environments (Lamontagne et al., 2000), as well as canopy trees and seedlings of tropical forests (Krause and Winter, 1996; Franco et al., 1999; Valio, 2001). Fluorescence variables used for evaluating PS II functioning include: initial fluorescence $\left(\mathrm{F}_{\mathrm{o}}\right)$, maximum fluorescence $\left(F_{m}\right)$ variable fluorescence $\left(F_{v}\right)$ and $F_{v} / F_{m}$ ratio (Shole and Horton, 1993). $F_{v}$ represents the difference between $F_{m}$ and $F_{o}\left(F_{v}=F_{m}-F_{o}\right)$. The $F_{o}$ parameter is the minimal fluorescence yielded when all reaction centers are in the oxidized or open state. When leaves are briefly exposed to a saturating light level, all PS II centers are closed. That is, quinone A (QA) is reduced and a maximum yield of fluorescence $\left(\mathrm{F}_{\mathrm{m}}\right)$ is observed. The $\mathrm{F}_{\mathrm{v}} / \mathrm{F}_{\mathrm{m}}$ ratio, calculated as $\mathrm{F}_{\mathrm{v}} / \mathrm{F}_{\mathrm{m}}=\left(\mathrm{F}_{\mathrm{m}}-\mathrm{F}_{\mathrm{o}}\right) / \mathrm{F}_{\mathrm{m}}$ is a fluorescence variable directly correlated with the physiological efficiency of the photosynthetic machinery. This ratio is been considered to be proportional to the quantum efficiency of PS II (Bjorkman and Demming, 1987). In a wide number of plant species and ecotypes, an $\mathrm{F}_{\mathrm{v}} / \mathrm{F}_{\mathrm{m}}$ ratio of 0.83 has been obtained in unstressed leaves. Hence, the effects of stressful environmental factors on PS II may be examined by determining the reduction in the $F_{v} / F_{m}$ ratio (Ogren and Evans, 1992; Sholes and Horton, 1993).

The species in the present study are from different stages in the successional scale. Swietenia macrophylla King (Meliaceae) and Dipteryx odorata Willd. (Fabaceae) are tropical species found in the Amazonian forest (Marenco, in press). They are found in primary forest but differ in their regeneration niche: late successional tonka bean can regenerate under closed forest canopy (Vieira, 1996), while mahogany needs large gaps for establishment (Tanaka, 1998; Morris et al., 2000). Therefore the latter species could be classified as mid-successional or gap opportunist (GomezPompa and Vázquez-Yanes, 1982). We hypothesize that species from different successional stages (e.g., shade tolerance or regeneration mode) respond differently to high levels of irradiance. To answer this question, we focused on the following objectives: a) changes in photosynthetic pigment concentrations and b) chlorophyll $a$ fluorescence in leaves of these two tropical species grown under contrasting light environments.

\section{MATERIALS AND METHODS}

The study was conducted in an experimental plantation near Presidente Figueiredo in the Brazilian Amazon (01 $51^{\prime} \mathrm{S} ; 6^{\circ} 04^{\prime} \mathrm{W}$ ). Mean annual temperature is about $27^{\circ} \mathrm{C}$ and annual precipitation ranges from 1750 to $2500 \mathrm{~mm}$. The soil is an oxisol, and $\mathrm{pH}$ ranges from 3.9 to 4.6. The area had remained as an abandoned pasture for about eight years and a mixed plantation was set up in May 1998 following a "quincôncio" system (one slow growth successional species neighbored by four fast growth pioneer species). Seedlings from both species (mahogany and tonka bean) were planted in holes spaced $3 \times 3 \mathrm{~m}$ apart. The seedlings were grown under shade and full sunlight 
about $2000 \mu \mathrm{mol}$ photons $\mathrm{m}^{-2} \mathrm{~s}^{-1}$. Shade was produced by balsa wood canopy (Ochroma pyramidale Cav. Ex Lam. Urb). Data for this study were collected from three-year-old saplings either grown under balsa wood canopy or in an open site. Mahogany saplings were $1.1 \mathrm{~m}$ tall, whereas tonka-been saplings were $4.30 \mathrm{~m}$ in height. By the time data were collected, balsa wood was about $11.1 \mathrm{~m}$ height and $15-20 \mathrm{~cm}$ DBH (diameter at breath height) and the leaf area index of its foliage (optically determined) was 2.46 (Licor - 2050 Lincoln, NE USA) with $13 \%$ of full sunlight about $260 \mu \mathrm{mol}$ photons $\mathrm{m}^{-2} \mathrm{~s}^{-1}$.

Chlorophyll and carotenoids were determined using a spectrophotometric method modified from Lichtenthaler (1983). For photosynthetic pigment determinations, ten plants per species were chosen at random and three fully expanded leaves per plant were collected, placed between layers of ice in a thermal insulated box and taken to the Amazon National Research Institute's (INPA) Plant Physiology laboratory where they were analyzed immediately. Leaf samples $(0.1 \mathrm{~g}$ fresh weigh or $3.0 \mathrm{~cm}^{2}$ ) were ground in an aqueous acetone solution $(80 \% \mathrm{v} / \mathrm{v})$ containing $\mathrm{MgCO}_{3}(0.5 \%$ $\mathrm{w} / \mathrm{v}$ ). After homogenization (Biohomogenizer $\mathrm{m}$ 133/1281 - ESGE, Bartlesville OK, USA), the samples were centrifuged at $5000 \mathrm{x} g$ for $5 \mathrm{~min}$ at $20^{\circ} \mathrm{C}$. The supernatant was used for determining absorbance at 480, 645 and $663 \mathrm{~nm}$ to obtain carotenoid and chlorophyll concentrations.

Fluorescence emission was assessed in fully expanded, in situ leaves between 9:00 and 11:00 am with a plant efficiency analyzer (PEA, MK2 - 9600 - Hansatech, Norfolk, UK). After 15 min dark adaptation, each leaf disc was exposed to a saturation pulse of high light intensity (2250 $\left.\mu \mathrm{mol} \mathrm{m}^{-2} \mathrm{~s}^{-1}\right)$ for five seconds and fluorescence variables $\left(\mathrm{F}_{\mathrm{o}}, \mathrm{F}_{\mathrm{m}}, \mathrm{F}_{\mathrm{v}}, \mathrm{F}_{\mathrm{v}} / \mathrm{F}_{\mathrm{m}}\right)$ were determined.

The experiment was an entirely randomized design with treatments arranged as a 2 x 2 factorial, with ten replications. The factors were: (1) two species (mahogany and tonka bean) and (2) two light environments (shade and sun).
Data were analyzed by using the analysis of variance and the means compared by Tukey test $(\mathrm{P}$ $=0.05$ ).

\section{RESULTS AND DISCUSSION}

Leaf chlorophyll concentrations (Chl $a$, $\mathrm{Chl} b$, Chl tot) on a fresh mass basis were higher in shade leaves than in sun leaves, for both species (Table 1). According to Tan et al. (2000) there is widespread interest in chlorophylls and their degradation reactions. Chlorophyll is synthesized and degraded (photooxidation) under irradiation. At high irradiance, however, the degradation rate overtakes the rate of synthesis, therefore, a lower chlorophyll concentration is observed. Due to this fact, shade leaves in comparison with sun leaves tend to show higher chlorophyll concentrations per unit leaf weight (Boardman, 1977). In addition, Chl $a$ and $\mathrm{Chl}$ tot concentrations were higher in tonka bean leaves than in mahogany, regardless of environments. It is worth noting that no differences were observed between species for Chl $b$ concentrations in either sun or shade plants. Slight differences in Chl $a / b$ ratio were observed both between species and environments. In the open site, the Chl $a / b$ ratio was higher in tonka bean than in mahogany, on a mass basis $(28 \%)$ or per unit area (44\%), respectively (Tables 1 and 2). In the shade environment $\mathrm{Chl} b$ concentration on a mass basis was higher in both species. This is particularly important because higher Chl $b$ levels allow light interception in wider wavelength bands. As a result, the transfer of a larger amount of energy to reaction centers is expected. For this reason the Chl $a / b$ ratio has been frequently used as an indicator of plant response to shading (Hendry and Price, 1993). Lower Chl $a / b$ ratios in mahogany saplings may indicate better acclimation to shade, while tonka bean appears to be better acclimated to the sunny environments.

Sun leaves of mahogany showed higher carotenoid concentrations on a mass basis or per unit area (Table 1 and 2). In contrast, tonka bean presented higher sun leaf carotenoid levels, which suggests that these species use different foraging 
strategies for light capture, depending on variations in light levels. Thus, either chlorophyll or carotenoid synthesis may increase to enhance acclimation to higher irradiation. Hendry and Price (1993) stressed that the chlorophyll/carotenoid ratio is a sensitive indicator of photoxidative damage. We observed that in both species the chlorophyll/carotenoid ratio was lower in the sunny environment, mainly on a mass basis (Table 1 ). This reduction was more pronounced in mahogany, 3.89 versus 2.06 for sun and shade leaves, respectively, suggesting that in this species both synthesis and carotenoid accumulation are very important as a mechanism for attenuating stress caused by high irradiance. The contrary was true for tonka bean. In this species the chlorophyll/carotenoid ratio was similar, 3.25 versus 2.97 (Table 1), indicating that its strategy for sun acclimation included other mechanisms such as thick and leathery leaves, in comparison to the thinner and tender leaves of mahogany. Both species are apparently quite different from each other in leaf anatomy and morphology. Furthermore, differences between species in terms of leaf anatomy (J.F.C.Gonçalves, pers. obs.) may indicate physiological differences between species relative to the synthesis and accumulation of photosynthetic pigments. In mahogany, pigment concentrations per unit leaf area (Table 2) showed no differences in chlorophyll concentrations between light environments. However, Chl $a$ and Chl tot concentrations were higher in tonka bean than in mahogany, both in sun and shade leaves. Nevertheless, there was no environmental effect on Chl tot and carotenoid concentration in tonka bean.

TABLE 1 - Leaf chlorophyll and carotenoid concentrations* ( $\mu$ mol.g $\left.{ }^{-1} \mathrm{FW}\right)$, chlorophyll $a / b$ and chorophyll/carotenoid ratio in mahogany and tonka bean under two light environments.

\begin{tabular}{|c|c|c|c|c|c|c|}
\hline & \multicolumn{2}{|c|}{ Mahogany } & \multicolumn{2}{|c|}{ Tonka bean } & \multirow[b]{2}{*}{$F$ ratio } & \multirow[b]{2}{*}{$P$ value } \\
\hline & Sun & Shade & Sun & Shade & & \\
\hline Chlorophyll $a$ & $1.16 \pm 0.38^{\mathrm{Bb}}$ & $2.12 \pm 0.15^{\mathrm{Ab}}$ & $1.77 \pm 0.24^{\mathrm{Ba}}$ & $2.94 \pm 0.22^{\mathrm{Aa}}$ & 74.69 & $<0.05$ \\
\hline Chlorophyll $b$ & $0.62 \pm 0.06^{\mathrm{Ba}}$ & $1.03 \pm 0.04^{\mathrm{Aa}}$ & $0.68 \pm 0.06^{\mathrm{Ba}}$ & $0.99 \pm 0.16^{\mathrm{Aa}}$ & 149.65 & $<0.05$ \\
\hline Chlorophyll Tot & $1.78 \pm 0.14^{\mathrm{Bb}}$ & $3.15 \pm 0.13^{\mathrm{Ab}}$ & $2.45 \pm 0.32^{\mathrm{Ba}}$ & $3.93 \pm 0.27^{\mathrm{Aa}}$ & 51.17 & $<0.05$ \\
\hline Carotenoids & $1.10 \pm 0.07^{\mathrm{Aa}}$ & $0.81 \pm 0.16^{\mathrm{Bb}}$ & $0.86 \pm 0.05^{\mathrm{Ba}}$ & $1.21 \pm 0.11^{\mathrm{Aa}}$ & 78.47 & $<0.05$ \\
\hline Chlorophyll $a / b$ ratio & 1.87 & 1.62 & 2.6 & 2.85 & - & - \\
\hline Chlorophyll/Carotenoids & 2.06 & 3.89 & 2.97 & 3.25 & - & - \\
\hline
\end{tabular}

* Means \pm standard deviation of ten replications. Means values followed by the same capital letters within a row for environments and lower case letter for species are not different at $\mathrm{P}=0.05$ using Tukey test. 
TABLE 2 - Leaf chlorophyll and carotenoid concentrations* $\left(\mu \mathrm{mol} . \mathrm{cm}^{-2}\right)$, chlorophyll $a / b$ and chlorophyll/carotenoid ratio in mahogany and tonka bean under two light environments.

\begin{tabular}{|c|c|c|c|c|c|c|}
\hline & \multicolumn{2}{|c|}{ Mahogany } & \multicolumn{2}{|c|}{ Tonka bean } & \multirow[b]{2}{*}{$F$ ratio } & \multirow[b]{2}{*}{$P$ value } \\
\hline & Sun & Shade & Sun & Shade & & \\
\hline Chlorophyll $a$ & $0.93 \pm 0.08^{\mathrm{Ab}}$ & $0.79 \pm 0.05^{\mathrm{Ab}}$ & $1.46 \pm 0.17^{\mathrm{Aa}}$ & $1.09 \pm 0.08^{\mathrm{Ba}}$ & 10.14 & $<0.05$ \\
\hline Chlorophyll $b$ & $0.33 \pm 0.02^{\mathrm{Aa}}$ & $0.33 \pm 0.01^{\mathrm{Aa}}$ & $0.29 \pm 0.07^{\mathrm{Bb}}$ & $0.37 \pm 0.06^{\mathrm{Aa}}$ & 8.81 & $<0.05$ \\
\hline Chlorophyll Tot & $1.26 \pm 0.09^{\mathrm{Ab}}$ & $1.12 \pm 0.07^{\mathrm{Ab}}$ & $1.65 \pm 0.65^{\mathrm{Aa}}$ & $1.46 \pm 0.11^{\mathrm{Aa}}$ & 16.77 & $<0.05$ \\
\hline Carotenoids & $0.57 \pm 0.06^{\mathrm{Aa}}$ & $0.46 \pm 0.07^{\mathrm{Ba}}$ & $0.54 \pm 0.04^{\mathrm{Aa}}$ & $0.47 \pm 0.03^{\mathrm{Aa}}$ & 29.00 & $<0.05$ \\
\hline Chlorophyll $a / b$ ratio & 2.82 & 2.39 & 5.03 & 2.95 & - & - \\
\hline Chlorophyll/Carotenoids & 2.21 & 2.43 & 3.06 & 3.11 & - & - \\
\hline
\end{tabular}

* Means \pm standard deviation of ten replications. Means values followed by the same capital letters within a row for environments and lower case letter for species are not different at $\mathrm{P}=0.05$ using Tukey test.

Chlorophyll concentration per unit leaf area is generally higher in sunny environments. However, some studies indicate a different relationship between irradiance and chlorophyll levels (Lee, 1988). Hence, plant response to irradiance may show a great deal of variability, in terms of chlorophyll concentration per unit leaf area. Thus, we may emphasize that an increase in carotenoid levels is an essential mechanism for mahogany acclimation to the sunny environment, which prevents photoxidative injury to chloroplast pigments. Krause et al. (1995) reported that young leaves contained more carotenoids than mature leaves under strong illumination in tropical forest. In tonka bean, however, leaf anatomy, in addition to physiological mechanisms, appears to be a determining factor for its acclimation to high irradiance.

The chlorophyll $a / b$ ratio declined in the shade environment in both species per unit area, but mainly in tonka bean leaves. Similar results have been observed in other species (Lee, 1988).
On the other hand, Tanaka (1998) did not observe any differences in the chl $a / b$ ratio of mahogany seedlings grown under different levels of shade. However, it is important to note that contrasting results may be observed if pigment concentrations were expressed per unit weight or on a leaf area basis.

Initial fluorescence was higher in sun leaves than in shade leaves of mahogany (Figure 1A), perhaps due to the degradation of $\mathrm{D} 1$ protein in PS II (Aro et al., 1994). However, there was no difference in $F_{0}$ values between environments in tonka bean leaves, suggesting a greater stability of the photosynthetic machinery in this species than in mahogany. In mahogany, $F_{m}$ was higher for leaves developed in the open site than under shading (Figure 1B). Conversely, in tonka bean, higher $\mathrm{F}_{\mathrm{m}}$ values were observed in the shade environment than in the open site. Lower $F_{m}$ values in sun leaves of tonka bean were attributed to a larger amount of energy released as heat (quenching capacity). On the other hand, $\mathrm{F}_{\mathrm{m}}$ values 
were lower in mahogany than in tonka bean in both environments, suggesting that energy dissipation as heat was less important for mahogany. Like $F_{o}$ and $\mathrm{F}_{\mathrm{m}}$ variables, the variable fluorescence in mahogany was also greater in the sunny environment than under shading. However $F_{v}$ was lower in sun leaves than in shade leaves for tonka bean (Figure 1C). Furthermore, within the environment, $F_{v}$ values were higher in tonka bean than in mahogany. In the open site the $\mathrm{F}_{\mathrm{v}} / \mathrm{F}_{\mathrm{m}}$ ratio was higher in tonka bean 0.77 (Figura 1D) than in mahogany 0.72 (Figure 1D), but no differences were observed between species in the shade environment. In addition, within each environment no differences in the $\mathrm{F}_{\mathrm{v}} / \mathrm{F}_{\mathrm{m}}$ ratio were observed. Kitao et al. (2000) examined the effects of strong light in combination with high temperatures on the photosynthetic system in four dipterocarp tree species and also observed little difference in $\mathrm{F}_{\mathrm{v}} / \mathrm{F}_{\mathrm{m}}$ ratio values among species.
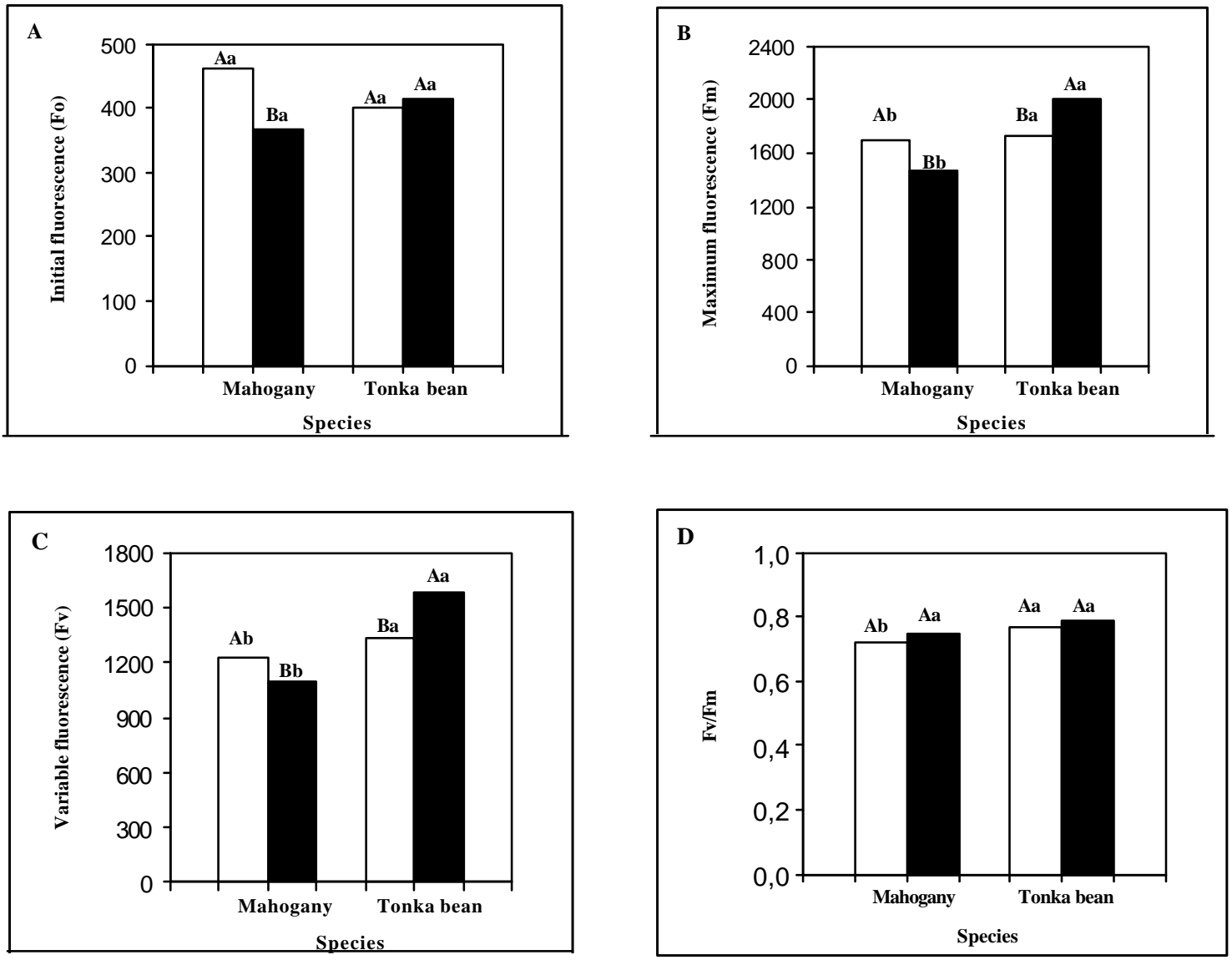

FIGURE 1 - Initial fluorescence $\left(\mathrm{F}_{\mathrm{o}}\right) \mathbf{A}$, maximum fluorescence $\left(\mathrm{F}_{\mathrm{m}}\right) \mathbf{B}$, variable fluorescence $\left(\mathrm{F}_{\mathrm{v}}\right) \mathbf{C}$, and $\mathrm{F}_{\mathrm{v}} / \mathrm{F}_{\mathrm{m}}$ fluorescence ratio $\mathbf{D}$ under two light environments, sun $(\square)$ and shade ( $\left.\boldsymbol{\square}\right)$. Capital letters show differences between environments and lower case letters show differences between species at $\mathrm{P}=0.05$ according to Tukey test. Each value is the mean of 10 replications. 
Gonçalves et al.

By examining fluorescence variables and pigment concentrations we found that, in the open site, tonka bean apparently experienced less damage than mahogany. However, the synthesis and accumulation of anti-oxidative pigments increased as a mechanism to prevent photoinhibitory damages in mahogany. Krause et al. (1995) reported that the high degree of reversible photoinhibition observed in young sun leaves probably represents a dynamic regulatory process protecting the photosynthetic apparatus from severe damage by excessive light. Since a $\mathrm{F}_{\mathrm{v}} / \mathrm{F}_{\mathrm{m}}$ ratio of 0.83 has been reported for unstressed plants (Krause and Weis, 1991), reductions of the $\mathrm{F}_{\mathrm{v}} / \mathrm{F}_{\mathrm{m}}$ ratio in this study may not seem severe. However, this may only reflect increased levels of photoprotection. In addition, both species may have grown at non-optimum light intensities and, as a result, differences with respect to synthesis, use and accumulation of photosynthetic pigments were observed. The plants used photosynthetic pigments either to increase light harvesting at low light levels or to prevent photoxidative damage under high solar radiation.

Our hypothesis was that species from different successional stages adapt differently their photosynthetic apparatus to changes in light environment. Mahogany showed greater physiological plasticity than tonka bean, which is consistent with results obtained recently by Marenco et al. (in press). Therefore, we concluded that these species use different strategies with respect to the mechanism of accumulation and uses of photosynthetic pigments. They increase light capture in shade environment, whereas protection against photoinhibition is increased in bright environments.

\section{ACKNOWLEDGEMENTS}

The study was supported by the Brazilian Ministry Science and Technology and the Brazilian Amazon Forest Research Project - Japanese International Cooperation Agency for financial support (Phase II project no: $309-1064$ - E - 1).

\section{REFERENCES}

ARO, N.R.; Mc CARRERY, S. \& ANDERSSON, J.M. Recovery from photoinibition in peas (Pisum sativum L.) acclimated to varying growth irradiances, Role of D1 protein turnover. Plant Physiology. 104:1119-1129, 1994.

BJÖRKMAN, O. \& DEMMING, B. Photon yield of $\mathrm{O}_{2}$ evolution and chlorophyll fluorescence characteristics at $77 \mathrm{~K}$ among vascular plants of diverse origins. Planta, 170:489-504, 1987.

BOARDMAN, N.K. Comparative photosynthesis of sun and shade plants. Annual Review of Plant Physiology, California, 28:355-377, 1977.

FRANCO, A.C.; HERZOG, B.; HUBNER, C.; MATTOS, E.A.; SCARANO, F.R.; BALL, E. \& LÜTTGE, U. Diurnal changes in chlorophyll a fluorescence, $\mathrm{CO}_{2}$ - exchange and organic acid decarboxylation in the tropical CAM tree Clusia hilariana. Tree Physiology 19:635-644, 1999.

GOMEZ-POMPA, G. \& VÁZQUEZ-YANES, C. Successional studies of a rain forest in Mexico.

In: Forest Succession Concepts and Applications, D.C. West, H.H Shugart e D.B. Botkin (Eds.), New York, 1982.

HENDRY, G.A.F. \& PRICE, A.H. Stress indicators: chlorophylls and carotenoids. In: Hendry, G.A.F. and Grime J.P. (Eds.) Methods in comparative plant ecology. Chapman \& Hall, London, 1993, 148-152p.

KAGEYAMA, P.Y. Genetic structure of tropical tree species of Brazil. In: Reproductive Ecology of Tropical Forest Plants. Ed. by K.S. Bawa and M. Hadley. Unesco, Paris, 1990, 421p.

KITAO, M.; LEI, T.T.; KOIKE, T.; TOBITA, H.; MARUYAMA, Y.; MATSUMOTO, Y. \& ANG, L.H. Temperature response and photoinhibition investigated by chlorophyll fluorescence measurements for four distinct species of dipterocarp trees. Physiologia Plantarum, 109:284-290, 2000. 
KRAUSE， G.H. \& WEIS, E. Chlorophyll fluorescence and photosynthesis: the basis. Annual Review of Plant Physiology and Plant Molecular Biology. 42:313-349, 1991.

KRAUSE, G.H. \& WINTER, K. Photoinhibition of photosynthesis in plants growing in natural tropical forest gaps. A chlorophyll fluorescence study. Botanical Acta, 109:456-462, 1996.

KRAUSE, G.H.; VIRGO, A. \& WINTER, K. High susceptibility to photoinhibition of young leaves of tropical forest trees. Planta, 197:4, 583-591, 1995.

LAMONTAGNE, M.; BIGRAS, F.J. \& MARGOLIS, H.A. Chlorophyll fluorescence and $\mathrm{CO}_{2}$ assimilation of black spruce seedlings following frost in different temperature and light conditions. Tree Physiology, 20:249-255, 2000 .

LEE, D.W. Simulating forest shade to study the development ecology of tropical plants: Juvenile growth in three vines in India. Journal of Tropical Ecology, 4:281-292, 1988.

LICHTENTHALER, H.K. \& WELLBURN, A.R. Determination of total carotenoids and chlorophylls $a$ and $b$ of leaf extracts in different solvents. Biochemical Society Transactions , 603, 591, 1983

MARENCO, R.A.; GONÇALVES, J.F.C. \& VIEIRA, G. Leaf gas exchange and carbohydrates in tropical trees deffering in successional status in two light environments in central Amazonian. Tree Physiology (in press).

MORRIS, M.H.; NEGREROS-CASTILLO, P. \& MIZE, C. Sowing date, shade, and irrigation affect big leaf mahogany (Swietenia macrophylla King). Forest Ecology and Management, 132:2-3, 173-181, 2000.
NEPSTAD, D.C.; VERÍSSIMO, A.; ALENCAR, A.; NOBRE, C.; LIMA, E.; LEFEBVRE, P.; SCHLESINGER, P.; POTTER, C.; MOUTINHO, P.; MENDOZA, E.; COCHRANE, M. \& BROOKS, V. Large-scale impoverishment of Amazonian forests by logging and fire. Nature, 398:505-508, 1999.

OGREN, E. \& EVANS, J.R. Photoinhibition of photosynthesis in situ in species of Eucalyptus. Australian Journal of Plant Physiology, 19: 224-232, 1992.

SHOLES, J.D. \& HORTON, P. Photosynthesis and chlorophyll fluorescence: simultaneous measurements. In: Hendry, G.A.F. and Grime J.P. (Eds.) Methods in comparative plant ecology. Chapman and Hall, London, 130-136, 1993.

STRAUSS-DEBENEDETTI, S. \& BAZZAZ, F.A. Plasticity acclimation to light in tropical Moraceae of different successional positions. Oecologia, 87:377-387, 1991.

TAN, Y.; JIANG, J.H.; WU, H.L.; CUI, H. \& YU, R.Q. Resolution of kinetic system of simultaneous degradation of chlorophyll $a$ and $b$ by PARAFAC. Analytica Chimica Acta, 412:195-202, 2000.

TANAKA, A. Ecofisiologia do estabelecimento de plântulas em plantios de enriquecimento em novo Aripuanã, Manaus. Instituto Nacional de Pesquisas da Amazônia, 137p., 1998. Tese de Mestrado.

VALIO, I.F.M. Effects of shading and removal of plant parts on growth of Trema micrantha seedlings. Tree Physiology, 21:65-70, 2001.

VIEIRA, G. Gap dynamics in managed Amazonian forest: Structural and ecophysiological aspects. Oxford, University of Oxford, 162p., 1996. Tese de Doutorado. 